\title{
Single and Combined Effects of Cadmium and Lead on Seed Germination and Early Seedling Growth in Rhus typhina
}

\author{
Tongbao Qu*, Yulan Peng, Chengxi Yang, Xue Du, Weiqianig Guo, Jianfeng Zhang \\ College of Horticulture, Jilin Agricultural University, Changchun City, Jilin Province, P. R. China
}

Received: 29 February 2020

Accepted: 16 May 2020

\begin{abstract}
Cadmium $(\mathrm{Cd})$ and lead $(\mathrm{Pb})$ generally occur simultaneously with low concentration in soil. However, anthropogenic activities have significantly raised these non-biodegradable heavy metals and caused long-term deleterious effects on ecosystem health. To study single or combined effects of Cd and $\mathrm{Pb}$ on seed germination, early seedling growth and physiological response in Rhus typhina, a seed germination and sand culture experiment was established completely randomized with $0,100,300$, and $500 \mathrm{mg} \cdot \mathrm{L}^{-1} \mathrm{~Pb}\left(\mathrm{NO}_{3}\right)_{2}$ or $0,25,75,125 \mathrm{mg} \cdot \mathrm{L}^{-1} \mathrm{CdCl}_{2}$ individually or in combination. The present results showed seed germination and seedling growth of Rhus typhina decreased with increasing $\mathrm{Cd}$ and $\mathrm{Pb}$, and the joint effect was more serious than single heavy metal stress. The lowest of seed germination rate (GR), germination index (GI), root length (RL) and shoot length (SL) in Rhus typhina decreased $65.85 \%, 73.46 \%, 84.33 \%$ and $61.95 \%$ compared to control in soil supplemented with combined Cd and $\mathrm{Pb}$, respectively. The activity of superoxide dismutase (SOD), peroxidase (POD), malondialdehyde (MDA) and soluble protein (SP) changed significantly with increasing concentration of $\mathrm{Cd}$ and $\mathrm{Pb}$, and MDA and POD played important roles in resisting $\mathrm{Cd}$ and $\mathrm{Pb}$ stress because of their significant correlation with seed germination and early seedling growth.
\end{abstract}

Keywords: Rhus typhina, Cd and Pb stress, MDA, Soluble Protein Content, SOD, POD

\section{Introduction}

During the last few decades, heavy metal contamination become one of the most noticeable environmental problems in developed as well as developing countries with the rapid development of industrial and modern agricultural practices [1]. Although soil heavy metals can naturally occur from the

*e-mail: qvtb@sina.com erosion of certain rocks and minerals, they are released in excess into the environment by anthropogenic activities such as the use of pesticides, agricultural fertilizers, industrial production, sewage, metalliferous mines, and transportation [2, 3]. These nonbiodegradable heavy metals in soil can cause long-term deleterious effects on ecosystem health as they can get absorbed by the root system and accumulate in different parts of plants, which disturbance plant physiological and metabolic processes, and further adversely affects human health and environment ecosystem by entering 
into the food chain in amount increases even at very low concentration [4-6]. Heavy metal toxicity in plants varies with specific metal and their content [1]. As the most hazardous pollutants presenting in agrochemicals and rich in industrially contaminated soils, $\mathrm{Cd}$ and $\mathrm{Pb}$ are the most toxic heavy metals and often occur simultaneously in soil, but single metals are commonly focused on toxic metal stress [7-9]. It was complex and important to understand the mechanisms of interaction between heavy metals due to design agronomic or genetic strategies to limit contamination of plants [10].

As the most significant stages in a seed plant's life, seed germination and seedling growth are the most sensitive to soil chemical and physical conditions, thus these parameters become the most prime important toxicity assays for detecting the inhibition effects caused by heavy metal [2, 11-13]. Many recent studies have confirmed that single heavy metals $\mathrm{Cd}$ or $\mathrm{Pb}$ and their interaction cause negatively influence on seed germination and seedling development by affected soluble protein (SP), malondialdehyde (MDA) and the degradation of antioxidant enzymes activities such as superoxide dismutase (SOD) and peroxidase (POD) [14-16]. However, some other experiments showed that seed germination was stimulated at low concentrations and inhabited under high concentrations, some other experiments documented gradual reduction in germination with concentration increase under single heavy metal stress [17-19].

More studies concentrated to the effects of combined heavy metal stress on herbaceous plants $[1,15]$. However, woody plants are more widely used in urban landscaping and play an immeasurable role in improving the ecological environment in the urban ecosystem. Rhus typhina L. (Anacardiaceae) is a perennial shrub or a small tree and it may clone through rhizomes and production by seeds [20, 21]. As an introduced species from eastern United States, Rhus typhina has been distributed in most areas of China with anthropogenic assistance due to its expansive, admittedly decorative and attractive tree, and it may pose a threat to the environment because ripening inflorescences during pollination may pose an allergic hazard to humans $[22,23]$. The fast-growing species with a brightly colored foliage tree during fall, has gradually become an ideal species for soil conservation and urban forestation because it can grow better under environmental stresses and highly effective retain water and soil [24]. Compared to agricultural soils, heavy metal pollution soil in urban is becoming more and more serious with the development of urbanization, so it is essential to better understand how the seed germination and seedling growth of $R$. typhina will be affected by the environmental factors such as heavy metal stress in its non-native habitats where it is widely planted $[25,26]$.

The aim was to detect the phytotoxic effects of $\mathrm{Cd}$ and $\mathrm{Pb}$ in Rhus typhina by investigating the morphological and physiological characteristics of seed germination and seedling growth of Rhus typhina under single or combine stress. With this experiment, we also evaluated how the contemporaneous presence of the $\mathrm{Cd}$ and $\mathrm{Pb}$ can affect each other. By examining, we will be able to assess its growth plasticity at different heavy metal pollution and to improve our mechanistic understanding of the survival and growth of $R$. typhina individuals in its introduced habitats. We hypothesized that the resistant capacity seed germination and seedling growth in $R$. typhina would be adversely affected by $\mathrm{Cd}$ and $\mathrm{Pb}$ stress, thus, to reveal whether it would be a potential species to resist heavy metal pollution.

\section{Materials and Methods}

\section{Materials}

Seeds of $R$. typhina were collected from campus of Jilin Agricultural University, Changchun (435' N, $125^{\circ} 21^{\prime}$ E), China in Oct 2017, Then sun-dried, stored at $4^{\circ} \mathrm{C}$. Heavy metal ions were made up in aqueous solutions at $\mathrm{Pb}(\mathrm{NO} 3)_{2}\left(100,300\right.$, and $\left.500 \mathrm{mg} \cdot \mathrm{L}^{-1}\right)$ and $\mathrm{CdCl}_{2}\left(25,75,125 \mathrm{mg} \cdot \mathrm{L}^{-1}\right)$ for germination tests.

\section{Seed Treatment and Seed Germination Experiments}

Seeds of $R$. typhina were firstly surface-sterilized ( $1 \% \mathrm{NaClO}$ for approximately $10 \mathrm{~min}$ ) and thoroughly washed with distilled water 3 times, then soaked into $90^{\circ} \mathrm{C}$ boiled water and kept for 24 hours after the water cooled down naturally, finally soaked in distilled water for 2 hours and dried with sterile filter paper. 30 seeds were distributed in $9 \mathrm{~cm}$ diameter Petri dishes, containing two sheets of filter paper, and $3 \mathrm{~mL}$ different concentrations of $\mathrm{Pb}\left(\mathrm{NO}_{3}\right)_{2}$ or/and $\mathrm{CdCl}_{2}$, and distilled water was used as a negative control. The samples were incubated in a climate-controlled incubator at $85 \%$ humidity with diurnal lighting (3500 lx light intensity, $25 \pm 1^{\circ} \mathrm{C}, 14 \mathrm{~h}$ light, and $20 \pm 1^{\circ} \mathrm{C}, 10 \mathrm{~h}$ dark) for 14 days. During the incubation, solution was supplied daily according to the amount of precipitation.

\section{Seed Germination and Seedling Growth Measurements}

The numbers of germinated seeds were counted daily at incubation time. Ten seedlings per Petri dish were selected at random for measurement. Germination rate (GR), germination index (GI), root length (RL) and shoot length (SL) were determined. Germination, defined as visible radicle emergence $(>2 \mathrm{~mm})$. GR was calculated by using the ratio of the final numbers of seed germination to the total numbers of seeds when no new germination occurred after 7 days of incubation. RL and SL were measured by using a digital caliper. 


\section{Physiological Measurements}

For heavy metal quantification, MDA, SP content, SOD and POD activities, were plotted under the same conditions. All these characteristics were evaluated at the end of the experiment with 14-day seedlings.

The content of MDA was determined by thiobarbituric acid (TBA) reaction, as described by Heath and Packer [27]. Firstly, $0.5 \mathrm{~g}$ of fully expanded leaves were grinding in solution containing $6 \mathrm{~mL} \mathrm{5 \%}$ $(\mathrm{v} / \mathrm{v})$ trichloroacetic acid by mortar, then the solution was centrifuged at $4,000 \mathrm{rpm}$ for $15 \mathrm{~min}$. Next, $2 \mathrm{~mL}$ of enzyme extract was taken and then added $2 \mathrm{~mL} 0.6 \%(\mathrm{v} / \mathrm{v})$ thiobarbituric acid. The mixture solution was heated at $100^{\circ} \mathrm{C}$ for 15 min using water bath, and then quickly cooled in an ice-water bath. Eventually, the solution was centrifuged at 4,000 rpm for $15 \mathrm{~min}$. The absorbance of the supernatant at 450, 532 and $600 \mathrm{~nm}$ was recorded. The content of MDA was calculated as follow follows: $\mathrm{C}_{(\mu \mathrm{M})}=6.45$ $\times\left(\mathrm{A}_{532}-\mathrm{A}_{600}\right)-0.56 \times \mathrm{A}_{450 ;} \mathrm{MDA}{ }_{(\mu \mathrm{mol} \cdot \mathrm{g}-1)}=\left(\mathrm{C} \times \mathrm{V}_{\mathrm{T}}\right)$ / $\left(1000 \times \mathrm{W}_{\mathrm{F}}\right)$. C: MDA concentration $(\mu \mathrm{M}) ; \mathrm{V}_{\mathrm{T}}$ : total volume of sample extract $(\mathrm{mL}) ; \mathrm{W}_{\mathrm{F}}$ : quality of fresh sample $(\mathrm{g})$.

$0.5 \mathrm{~g}$ fully expanded leaves of $R$. typhina were homogenized in a pre-chilled mortar and pestle with $6 \mathrm{~mL}$ of $50 \mathrm{mM}$ ice-cold $\mathrm{Na}_{2} \mathrm{HPO}_{4}-\mathrm{NaH}_{2} \mathrm{PO}_{4}$ buffer (pH 7.8) containing $0.1 \mathrm{mM} \mathrm{Na}$-EDTA and $1 \%(W / V)$ polyvinyl-polypirrolidone (PVP). The extract was centrifuged at $10000 \mathrm{rpm}$ for $15 \mathrm{~min}$ at $4^{\circ} \mathrm{C}$, and the supernatant was prepared for measurement of SP content, SOD and POD activity.

The SP content in the supernatant was determined using the dye-binding method by Bradford [28], the absorbance of the reaction solution was measured at $595 \mathrm{~nm}$ after $2 \mathrm{~min}$ and before $1 \mathrm{~h}$ using a spectrophotometer (ultraviolet-2006). The activity SOD was determined by monitoring its ability to inhibit the photochemical reduction of nitroblue tetrazolium chloride (NBT). The absorbance of the irradiated solution was recorded at $560 \mathrm{~nm}$ with a spectrophotometer (ultraviolet-2006), and one unit SOD activity was defined as the amount of extract required to cause $50 \%$ inhibition of the rate of NBT reduction at $560 \mathrm{~nm}$ [29]. The POD activity was determined by the change in absorbance of $\mathrm{OD}_{470}$ due to guaiacol oxidation according to the method described by Polle [30].

\section{Statistical Analysis}

All treatment values are expressed as mean of five replicates \pm standard deviation (SD). Data were analyzed by analysis of variance (ANOVA) using SPSS (SPSS Statistics, Shanghai, China, version 17.0) to evaluate the effect of $\mathrm{Pb}, \mathrm{Cd}$ and their interaction on the growth indexes and physiological measurements. Statistically significant differences were set at $P<0.05$. Duncan's new multiple range tests were calculated when treatments were significantly different at 0.05 level.

\section{Results}

\section{$\mathrm{Pb}$ and $\mathrm{Cd}$ Inhibited Seed Germination of $R$. typhina}

The GR and GI of R. typhina seed greatly decreased with the concentration of $\mathrm{Pb}^{2+}$ and $\mathrm{Cd}^{2+}$ increased $(P<0.05)$. GR decreased by $6.09-25.61 \%$ and $6.09-34.15 \%$, and GI decreased by $10.2-22.35 \%$ and $3.91-41.62 \%$ under stress of single $\mathrm{Pb}^{2+}$ and $\mathrm{Cd}^{2+}$, respectively (Fig. 1, Table 1). Interactive effects of two heavy metal pollutants $\mathrm{Cd}$ and $\mathrm{Pb}$ in seed GR and GI were examined on their stress, GR and GI significantly decreased by $21.95-65.85 \%$ and $35.89-73.46 \%(P<0.05)$ (Fig. 1, Table 1). Compared with single heavy metal stress, combine stress significantly inhibited seed germination of $R$. typhina. When the concentration of $\mathrm{Pb}^{2+}, \mathrm{Cd}^{2+}$ and combine heavy metal stress was at $500 \mathrm{mg} \cdot \mathrm{L}^{-1}$, $125 \mathrm{mg} \cdot \mathrm{L}^{-1}$ and $\mathrm{Pb}^{2+} 500 \mathrm{mg} \cdot \mathrm{L}^{-1}+\mathrm{Cd}^{2+} 125 \mathrm{mg} \cdot \mathrm{L}^{-1}$, there were the lowest GR $(67.78 \%, 60 \%$ and $31.11 \%)$ and GI (5.56, 4.18 and 1.9), respectively $(P<0.05)$ (Fig. 1, Table 1).

\section{$\mathrm{Pb}$ and $\mathrm{Cd}$ inhibited Seedling Growth}

Single $\quad \mathrm{Pb} \quad$ stress $\quad$ under $\quad 100 \mathrm{mg} \cdot \mathrm{L}^{-1} \quad$ slightly promoted the root growth, while high concentration $\mathrm{Pb}$
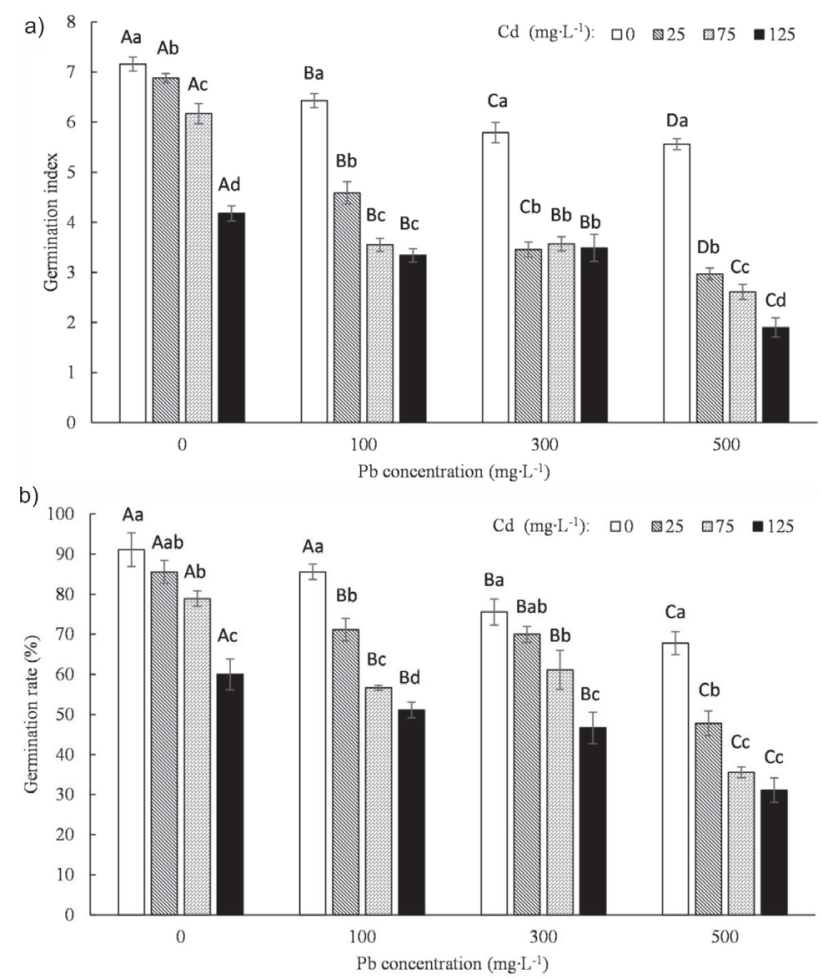

Fig. 1 Effect of $\mathrm{Cd}$ and $\mathrm{Pb}$ on Germination rate and Germination index of $R$. typhina. Each value represents mean $\pm \mathrm{SE}$. Significant differences between different $\mathrm{Cd}$ concentration levels within $\mathrm{a} \mathrm{Pb}$ concentration are indicated by lowercase letters (a-d); significant differences between different $\mathrm{Pb}$ concentration within a $\mathrm{Cd}$ concentration are indicated by capital letters (A-D; $P<0.05$ ). 
Table 1. ANOVA analysis of $\mathrm{Pb}^{2+}$ and $\mathrm{Cd}^{2+}$ on seed germination rate (GR), germination index (GI), root length (RL) and shoot length (SL).

\begin{tabular}{|c|c|c|c|c|c|}
\hline \multirow{2}{*}{ Factors } & \multirow{2}{*}{ DF } & GR & GI & $\mathrm{RL}$ & SL \\
\hline & & $F \quad P$ & $F$ & $F \quad P$ & $F \quad P$ \\
\hline $\mathrm{Pb}^{2+}$ & 3 & $121.991<0.001$ & $70.337<0.001$ & $273.043<0.001$ & $83.045<0.001$ \\
\hline $\mathrm{Cd}^{2+}$ & 3 & $116.353<0.001$ & $59.678<0.001$ & $361.484<0.001$ & $82.858<0.001$ \\
\hline $\mathrm{Pb}^{2+} \times \mathrm{Cd}^{2+}$ & 9 & $\begin{array}{ll}3.084 & 0.009\end{array}$ & $3.354 \quad 0.005$ & $27.105<0.001$ & $2.209 \quad 0.048$ \\
\hline
\end{tabular}

significantly inhibited the growth of roots and shoots of $R$. typhina. Compared with control, single $\mathrm{Pb}$ stress at $500 \mathrm{mg} \cdot \mathrm{L}^{-1}$ caused $60.54 \%$ and $25.73 \%$ decrease in root and shoot length, respectively (Fig. 2, Table 1). $\mathrm{RL}$ and SL significantly decreased with the increase of externally supplied Cd. Single $\mathrm{Cd}$ stress caused a $8.15-55.95 \%$ and $10.07-35.02 \%$ decrease in root and shoot length, respectively (Fig. 2, Table 1). The lowest RL $(13.52 \mathrm{~mm})$ and SL $(19.95 \mathrm{~mm})$ were observed at Cd 125 , respectively.

Compared with control and single heavy metal stress, combined $\mathrm{Pb}$ and $\mathrm{Cd}$ stress significantly inhibited seedling growth of $R$. typhina, and RL and SL significantly decreased with the increase of $\mathrm{Pb}$ and Cd. Compared with control, combine heavy metal stress caused a $1.50-84.33 \%$ RL and $16.52-61.95 \%$ SL decrease, respectively (Fig. 2, Table 1). The lowest RL
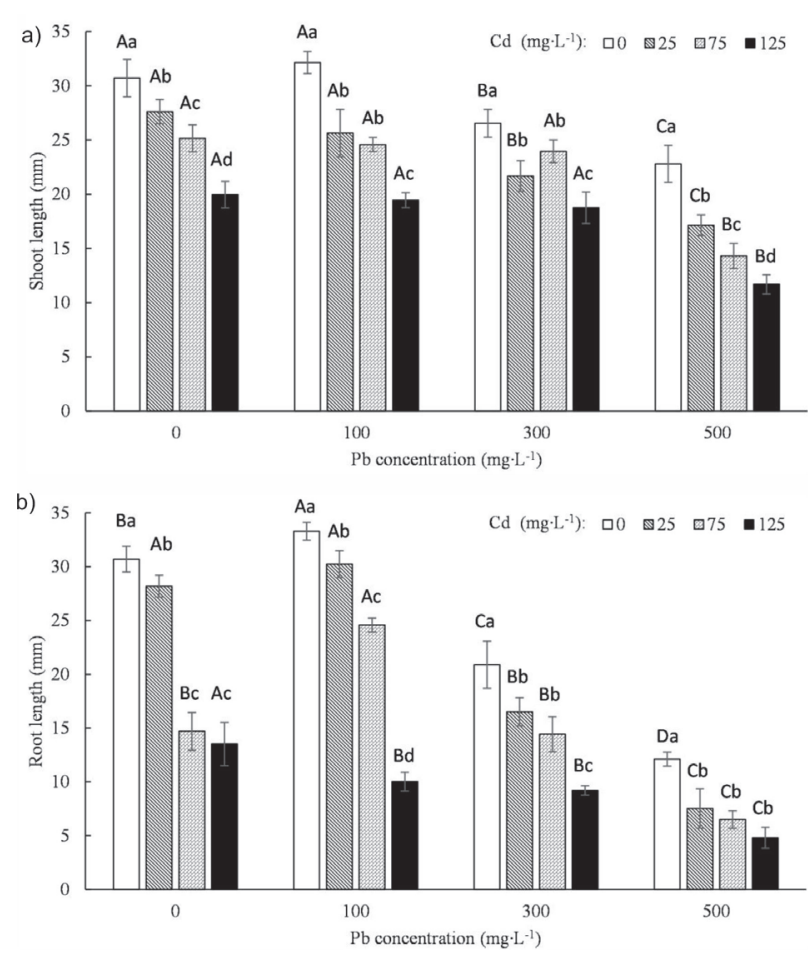

Fig. 2 Effect of $\mathrm{Cd}$ and $\mathrm{Pb}$ on Root length and shoot length of $R$. typhina. Each value represents mean \pm SE. Significant differences between different $\mathrm{Cd}$ concentration levels within a $\mathrm{Pb}$ concentration are indicated by lowercase letters (a-d); significant differences between different $\mathrm{Pb}$ concentration within a $\mathrm{Cd}$ concentration are indicated by capital letters (A-D; $P<0.05)$. and SL were $4.84 \mathrm{~mm}$ and $11.68 \mathrm{~mm}$ at $\mathrm{Pb} 500 \mathrm{mg} \cdot \mathrm{L}^{-1}$ and $\mathrm{Cd} 125 \mathrm{mg} \cdot \mathrm{L}^{-1}$, decreased by $84.33 \%$ and $61.99 \%$, respectively.

\section{$\mathrm{Pb}$ and $\mathrm{Cd}$ Impacted MDA and Soluble Protein Content}

MDA content significantly increased with the increase of single externally heavy metal $\mathrm{Pb}$ and Cd stress (Fig. 3). Compared to control, the highest MDA content at $500 \mathrm{mg} \cdot \mathrm{L}^{-1} \mathrm{~Pb}$ was $21.4 \mathrm{nmol} \cdot \mathrm{g}^{-1}$ $\mathrm{FW}$, or $125 \mathrm{mg} \cdot \mathrm{L}^{-1} \mathrm{Cd}$ stress was $27.15 \mathrm{nmol} \cdot \mathrm{g}^{-1} \mathrm{FW}$, which significantly increased by $35.87 \%$ and $72.38 \%$, respectively (Fig. 3, Table 1). The percent of increase in MDA content was relatively more in the single heavy stress of $\mathrm{Cd}$ than $\mathrm{Pb}$. At combined heavy metal stress treatment, MDA content significantly increased with the increase of $\mathrm{Cd}$ concentration at $\mathrm{Pb} 500 \mathrm{mg} \cdot \mathrm{L}^{-1}$, however, there was no significant in MDA content between different $\mathrm{Pb}$ concentration at $\mathrm{Cd} 125 \mathrm{mg} \cdot \mathrm{L}^{-1}$. Although there was a significant interaction effect in $\mathrm{Pb}$ and $\mathrm{Cd}$, MDA content was affected by $\mathrm{Pb}$ concentration when $\mathrm{Cd}$ reaches the maximum concentration $125 \mathrm{mg} \cdot \mathrm{L}^{-1}$ (Fig. 3, Table 2).

Single heavy metal $(\mathrm{Pb}$ or $\mathrm{Cd})$ stress significantly increased soluble protein (SP) content (Fig. 3b). The highest SP content was observed $10.64 \mathrm{mg} \cdot \mathrm{g}^{-1}$ at single $\mathrm{Pb} 500 \mathrm{mg} \cdot \mathrm{L}^{-1}$ or $6.06 \mathrm{mg} \cdot \mathrm{g}^{-1}$ at single $\mathrm{Cd}$ $75 \mathrm{mg} \cdot \mathrm{L}^{-1}$, as compared with control, SP content significantly increased by 3.124 times and 1.359 times, respectively (Fig. 3b). Combined $\mathrm{Pb}$ and $\mathrm{Cd}$ stress also significantly increased SP content compared with control, but it was significant different between different $\mathrm{Pb}$ stress at same $\mathrm{Cd}$ stress. SP content increased and then decreased as the concentration of $\mathrm{Pb}$ increases at $\mathrm{Cd} 25 \mathrm{mg} \cdot \mathrm{L}^{-1}$, while decreased with the increase of $\mathrm{Pb}$ concentration at $\mathrm{Cd} 75 \mathrm{mg} \cdot \mathrm{L}^{-1}$ and $125 \mathrm{mg} \cdot \mathrm{L}^{-1}$ (Fig. 3b). The highest and the lowest SP content were $11.15 \mathrm{mg} \cdot \mathrm{g}^{-1}$ and $3.51 \mathrm{mg} \cdot \mathrm{g}^{-1}$ at combined stress, which increased by 3.322 times and 0.361 times compared with control, respectively (Fig. 3b).

\section{$\mathrm{Pb}$ and $\mathrm{Cd}$ Impacted Antioxidant Enzymes SOD and POD Activities}

SOD activities fluctuated in different concentration of single $\mathrm{Pb}$ stress compared to the control, the dynamic tendency of SOD ascended, and then declined below 


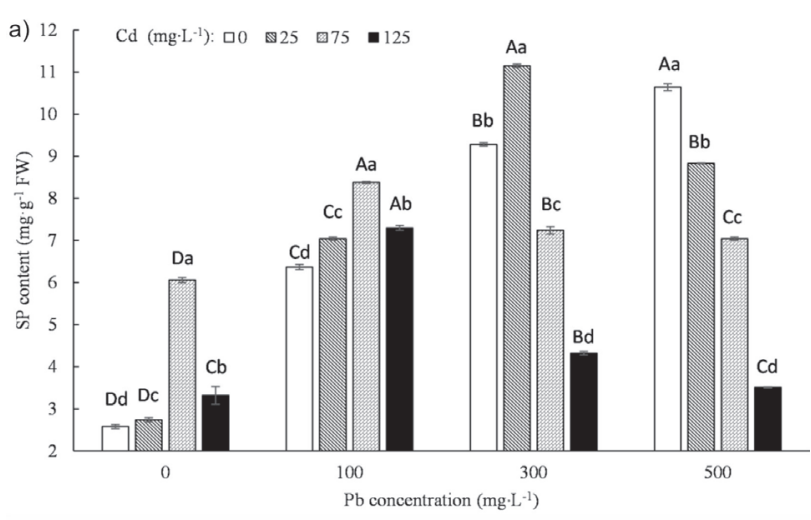

b)

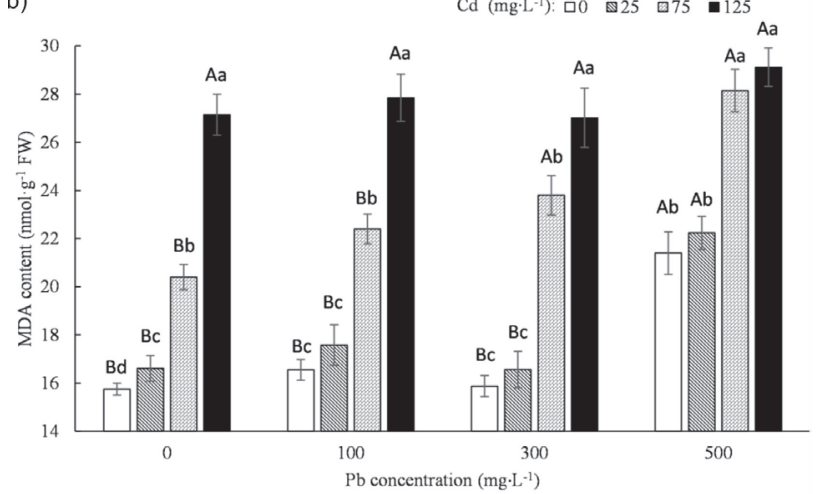

Fig. 3 Effect of $\mathrm{Cd}$ and $\mathrm{Pb}$ on malondialdehyde (MDA) and soluble protein (SP) of $R$. typhina. Each data point represents mean \pm SE. Significant differences between different $\mathrm{Cd}$ concentration levels within a $\mathrm{Pb}$ concentration are indicated by lowercase letters (a-d); significant differences between different $\mathrm{Pb}$ concentration within a $\mathrm{Cd}$ concentration are indicated by capital letters (A-D; $P<0.05$ ).

control levels at $500 \mathrm{mg} \cdot \mathrm{L}^{-1} \mathrm{~Pb}$ (Fig. 4a). The highest SOD was $214.86 \mathrm{U} \cdot \mathrm{g}^{-1}$ at $100 \mathrm{mg} \cdot \mathrm{L}^{-1}$ and the lowest was $104.79 \mathrm{U} \cdot \mathrm{g}^{-1}$ at $500 \mathrm{mg} \cdot \mathrm{L}^{-1}$, which increased by $53.82 \%$ and decreased by $24.98 \%$ in single $\mathrm{Pb}$ stress compared with control, respectively (Fig. 4a). While SOD activity decreased with the increase of single $\mathrm{Cd}$ stress concentration, the lowest SOD was $14.292 \mathrm{U} \cdot \mathrm{g}^{-1}$ at $125 \mathrm{mg} \cdot \mathrm{L}^{-1}(P<0.05)$. In combine heavy metal stress, SOD activity all significantly declined with ascend of one heavy metal stress at another heavy metal stress except $300 \mathrm{mg} \cdot \mathrm{L}^{-1} \mathrm{~Pb}$ and $75 \mathrm{Cd} \mathrm{mg} \cdot \mathrm{L}^{-1}$ (Fig. 4a). The lowest SOD was $26.10 \mathrm{U} \cdot \mathrm{g}^{-1}$ at $500 \mathrm{mg} \cdot \mathrm{L}^{-1} \mathrm{~Pb}$ and $125 \mathrm{Cd} \mathrm{mg} \cdot \mathrm{L}^{-1}$ (Fig. 4a), which decreased by $81.31 \%$.

In single heavy metal stress, POD activity significantly increased with the increase of $\mathrm{Pb}$ or $\mathrm{Cd}$

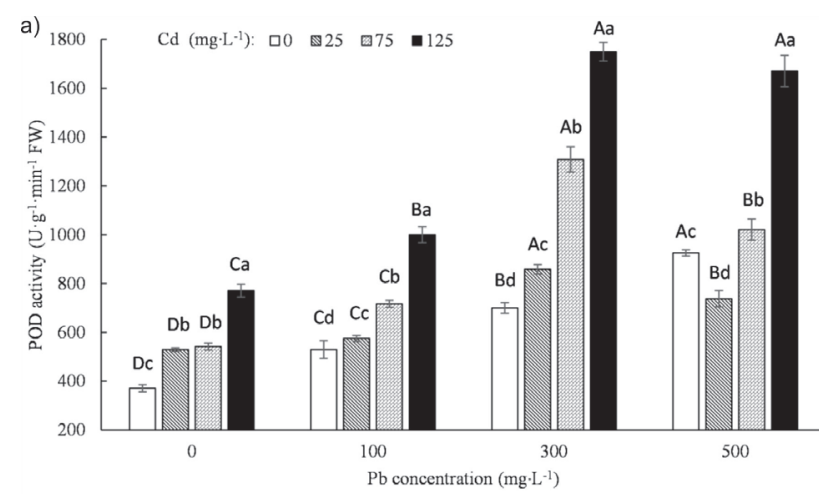

b)

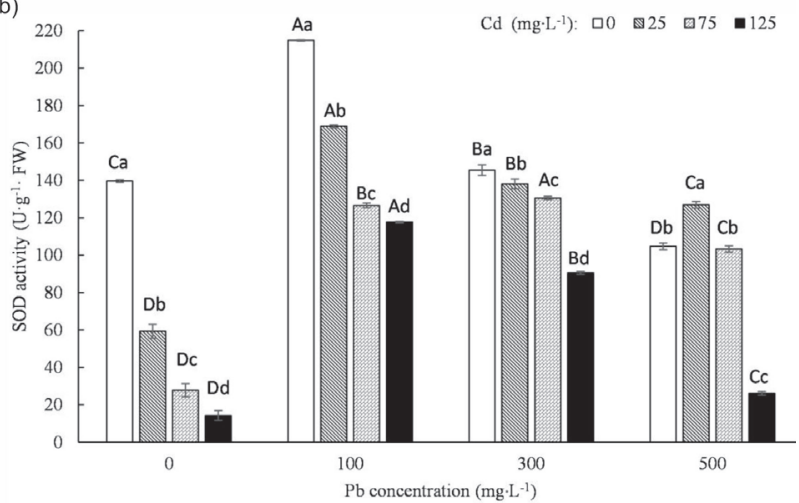

Fig. 4 Effect of $\mathrm{Cd}$ and $\mathrm{Pb}$ on superoxide dismutase (SOD) and peroxidase (POD) activity of $R$. typhina. Each value represents mean \pm SE. Significant differences between different $\mathrm{Cd}$ concentration levels within a $\mathrm{Pb}$ concentration are indicated by lowercase letters (a-d); significant differences between different $\mathrm{Pb}$ concentration within a $\mathrm{Cd}$ concentration are indicated by capital letters (A-D; $P<0.05)$.

stress except no significant different between $25 \mathrm{mg} \cdot \mathrm{L}^{-1}$ and $75 \mathrm{mg} \cdot \mathrm{L}^{-1}$ single $\mathrm{Cd}$ stress (Fig. 4b). Compared to control, the highest POD at $500 \mathrm{mg} \cdot \mathrm{L}^{-1} \mathrm{~Pb}$ and $125 \mathrm{mg} \cdot \mathrm{L}^{-1}$ $\mathrm{Cd}$ stress were $925 \mathrm{U} \cdot \mathrm{g}^{-1} \cdot \mathrm{min}^{-1}$ and $770 \mathrm{U} \cdot \mathrm{g}^{-1} \cdot \mathrm{min}^{-1}$, which significantly increased by $149.44 \%$ and $107.87 \%$, respectively (Fig. 4b, Table 2). In combined heavy metal stress, POD activity all significantly increased with the increase of $\mathrm{Cd}$ stress at same $\mathrm{Pb}$ level, while POD firstly significantly increased, and then declined with the increase of $\mathrm{Pb}$ concentration at same $\mathrm{Cd}$ level except no statistic significant changes between $\mathrm{Pb} 300 \mathrm{mg} \cdot \mathrm{L}^{-1}$ and $500 \mathrm{mg} \cdot \mathrm{L}^{-1}$ at $\mathrm{Cd} 125 \mathrm{mg} \cdot \mathrm{L}^{-1}$ (Fig. 4b, Table 2). The highest POD activity was $1750 \mathrm{U} \cdot \mathrm{g}^{-1} \cdot \mathrm{min}^{-1}$ at $\mathrm{Pb}$ $300 \mathrm{mg} \cdot \mathrm{L}^{-1}$ and $\mathrm{Cd} 125 \mathrm{mg} \cdot \mathrm{L}^{-1}$, which ascended by $371.91 \%$ compared with control $(P<0.05)$.

Table 2. ANOVA analysis of $\mathrm{Pb}^{2+}$ and $\mathrm{Cd}^{2+}$ on MDA, soluble protein (SP), SOD and POD.

\begin{tabular}{|c|c|c|c|c|c|}
\hline \multirow{2}{*}{ Factors } & \multirow{2}{*}{ DF } & MDA & SP & SOD & POD \\
\hline & & $F \quad P$ & $F$ & $F$ & $F$ \\
\hline $\mathrm{Pb}^{2+}$ & 3 & $373.718<0.001$ & $2627.049<0.001$ & $5503.596<0.001$ & $674.270<0.001$ \\
\hline $\mathrm{Cd}^{2+}$ & 3 & $67.074<0.001$ & $6295.351<0.001$ & $6754.191<0.001$ & $619.157<0.001$ \\
\hline $\mathrm{Pb}^{2+} \times \mathrm{Cd}^{2+}$ & 9 & $7.307<0.001$ & $2241.736<0.001$ & $622.261<0.001$ & $53.921<0.001$ \\
\hline
\end{tabular}


Table 3. Pearson correlation matrix for $\mathrm{Pb}^{2+}, \mathrm{Cd}^{2+}$ concentrations and seed germination rate (GR), germination index (GI), root length (RL) and shoot length (SL), MDA, soluble protein (SP), SOD and POD of Rhus typhina

\begin{tabular}{|c|c|c|c|c|c|c|c|c|c|c|}
\hline Items & $\mathrm{Pb}^{2+}$ & $\mathrm{Cd}^{2+}$ & $\mathrm{GR}$ & $\mathrm{GI}$ & $\mathrm{RL}$ & $\mathrm{SL}$ & $\mathrm{MDA}$ & $\mathrm{SP}$ & $\mathrm{SOD}$ & $\mathrm{POD}$ \\
\hline $\mathrm{Pb}^{2+}$ & 1 & & & & & & & & & \\
\hline $\mathrm{Cd}^{2+}$ & 0 & 1 & & & & & & & & \\
\hline $\mathrm{GR}$ & $-.642^{* *}$ & $-.679^{* *}$ & 1 & & & & & & & \\
\hline $\mathrm{GI}$ & $-.578^{* *}$ & $-.631^{* *}$ & $.893^{* *}$ & 1 & & & & & & \\
\hline $\mathrm{RL}$ & $-.665^{* *}$ & $-.612^{* *}$ & $.806^{* *}$ & $.713^{* *}$ & 1 & & & & & \\
\hline $\mathrm{SL}$ & $-.645^{* *}$ & $-.637^{* *}$ & $.904^{* *}$ & $.814^{* *}$ & $.871^{* *}$ & 1 & & & & \\
\hline $\mathrm{MDA}$ & $.308^{*}$ & $.872^{* *}$ & $-.820^{* *}$ & $-.692^{* *}$ & $-.734^{* *}$ & $-.753^{* *}$ & 1 & & & \\
\hline $\mathrm{SP}$ & $.486^{* *}$ & $-.335^{*}$ & -.084 & -.189 & -.217 & -.066 & -.162 & & 1 & \\
\hline $\mathrm{SOD}$ & .027 & $-.619^{* *}$ & $.324^{*}$ & .185 & $.531^{* *}$ & $.489^{* *}$ & $-.533^{* *}$ & $.404^{* *}$ & 1 & \\
\hline $\mathrm{POD}$ & $.580^{* *}$ & $.662^{* *}$ & $-.745^{* *}$ & $-.708^{* *}$ & $-.699^{* *}$ & $-.685^{* *}$ & $-.692^{* *}$ & -.031 & $-.307^{*}$ & 1 \\
\hline
\end{tabular}

** Correlation is significant at the 0.01 level (2-tailed).* Correlation is significant at the 0.05 level (2-tailed).

\section{Correlation of $\mathrm{Pb}$ and $\mathrm{Cd}$ Stress on Seed Germination and Seedling Growth}

Pearson correlation analysis showed that morphological and physiological parameters of seed germination and seedling growth in Rhus typhina were strongly affected by $\mathrm{Pb}$ and $\mathrm{Cd}$ concentrations except $\mathrm{SOD}$ under $\mathrm{Pb}$ stress (Table 3). $\mathrm{Pb}$ and $\mathrm{Cd}$ stress had significant negative correlations with all morphological indicators and significant positive with MDA and POD. Pb had significant positive correlations with SP, nevertheless, Cd had significant negative correlations with SP and SOD. MDA and POD had significant negative with all morphological indicators of seed germination and seedling growth in Rhus typhina, while SOD had significant positive with GR, RL and SL. The highest correlation of heavy metal stress was observed in Cd and GR of morphological parameters with 0.679 values, and MDA of physiological parameters with 0.872 values $(P<0.01)$.

\section{Discussion}

The present study examined the single and combined effects of the two key metal pollutants $\mathrm{Cd}$ and $\mathrm{Pb}$ in growth medium on their uptake and the contribution of oxidative stress in expression of their toxicities during establishment of Rhus typhina seedlings, in order to understand the combined effects of $\mathrm{Cd}$ and $\mathrm{Pb}$ on seed germination and early seedling growth in Rhus typhina and possible relationship of individual and combined excess levels as well as the response of antioxidative defence system of Rhus typhina seedlings.

Heavy metal contamination of soil causing toxicity has become one of the most damaging abiotic stress to restrict the survival and development of plants $[31,32]$. Seed germination is the starting point in the life cycle of a plant and is also the earliest stage of a plant's exposure to heavy metal stress, so detection of seed germination and seedling growth index is a good method to examine the capacity of higher plants to heavy metal toxicity pollutant $[25,33,34]$. Some previous studies and our results clearly indicate that seed germination and seedling growth index of higher plant significantly affected by $\mathrm{Cd}$ and/or $\mathrm{Pb}$ stress and greatly decreased with the concentration increased, regardless of whether individual effects of each metal or combined treatment [12, 35] (Figs 1-2, Table 3). Unlike other heavy metals $(\mathrm{Cu}, \mathrm{Zn}, \mathrm{Mn}$, etc.) are considered as micronutrients by promoting seed germination and seedling growth in low concentrations and inhibiting in high concentrations, both $\mathrm{Pb}$ and $\mathrm{Cd}$ are known phytotoxicant to disturb metabolic and growth processes even at very low concentrations being nonessential for plant metabolic activities and without physiological function in plants [1, 36, 37]. Furthermore, compared with single heavy metal treatment, the toxicity on seed germination and seedling growth of Rhus typhina was strengthened remarkably under combined heavy metal stress (Figs 1-2). This phenomenon can be attributed to the synergistic effects of $\mathrm{Cd}$ and $\mathrm{Pb}$ [38].

MDA is generally used to indicate the degree of plant cell membrane damage as one final decomposition product of lipid peroxidation, and reflected the ROS level under heavy metal stress [39]. Our results showed an appreciable rise in MDA and SP compared to no heavy metal stress under single or combined $\mathrm{Pb}$ and $\mathrm{Cd}$ stress due to the free radical-induced membrane damage (Fig. 3). MDA significantly increased and correlated with the increase of single and combined $\mathrm{Pb}$ and $\mathrm{Cd}$ stress (Fig. 3a and Table 3). Nevertheless, different responses were observed in SP from MDA when exposed to $\mathrm{Pb}$ and various $\mathrm{Cd}$ levels (Fig. 3). $\mathrm{Cd}$ and $\mathrm{Pb}$ could induce plants to synthesize Phytochelatin (PC), and $\mathrm{Pb}$ could be complexed with metallothionein (MT) 
to form metallothionein complex (Pb-MT) at their low concentrations to alleviate the toxicity of heavy metal stress to plant cells, which could be reflected by soluble proteins [40]. However, plant cells were damaged by excess heavy metal ions due to the inhibit expression of $\mathrm{Pb}-\mathrm{MT}$ and $\mathrm{Cd}-\mathrm{PC}$ with the increase of heavy metals, so SP content decreased. Pearson correlation analysis in present studies showed that although heavy metal stress caused the increase of SP, it was not related to the indicators of seed germination and seedling growth in Rhus typhina (Table 3 ).

Heavy metals stress can induce plants to produce reactive oxygen species (ROS) which can interact with DNA, pigments, proteins, lipids, and other essential cellular macromolecules ultimately leading to a chain of destructive processes [41, 42]. Being sessile organisms, plants have to develop a specific mechanism known as the plant antioxidant defense system that regulates ROS levels to keep ROS at physiological limit, preventing them from exceeding toxic threshold levels in the cellular system at a particular time [43]. As two primary antioxidative enzyme, previous studies revealed that SOD and POD play a relevant role in treatment of heavy metal enhances ROS formation [44, 45]. SOD can eliminate $\mathrm{O}^{2-}$, decrease peroxidation of membrane lipids and maintain cell membrane stability, and POD participate in the decomposition of $\mathrm{H}_{2} \mathrm{O}_{2}[25,46]$. In the present study and other studies showed that the activities of POD significantly increased and correlated with heavy metal stress, suggesting that plants adjusted their POD activity to protect membrane stability from heavy metal-induced oxidative damage [37, 47] (Fig. 4 and Table 3). Interestingly, our experiment showed that SOD activity significantly decreased with the increase of $\mathrm{Cd}$ stress whether $\mathrm{Pb}$ is presence or not, except in $500 \mathrm{mg} \cdot \mathrm{L}^{-1} \mathrm{~Pb}$, but first increased and then decreased under $\mathrm{Pb}$ stress in the presence of $\mathrm{Cd}$ (Fig. 4). Although many experiments showed that the activity of SOD increased with the concentration of $\mathrm{Cd}$ and $\mathrm{PB}$ under single and combined stress, some previous studies also showed that $\mathrm{Pb}$ or $\mathrm{Cd}$ inhibited the SOD activity, who concluded that it may be the dynamic balance of ROS is broken by the excessive accumulation of ROS under elevated concentrations of heavy metal stress in plants [48, 49]. Heavy metals could produce severe toxicity symptoms which destroyed the antioxidant enzyme system in plants. These results suggested that plant antioxidant enzymes have different sensitivity to $\mathrm{Pb}$ and $\mathrm{Cd}$ stress which results in different antioxidant enzyme response ability in different plant species [50, 51, 52]. These results also indicated that there were significant ion interactions and antagonistic effects between $\mathrm{Pb}$ and Cd (Fig. 4 and Table 3).

\section{Conclusions}

In summary, $\mathrm{Cd}$ and $\mathrm{Pb}$ stress significantly influenced early plant growth in Rhus typhina, and seed germination and seedling growth of Rhus typhina decreased with increasing $\mathrm{Cd}$ and $\mathrm{Pb}$, and the joint effect was more serious than single stress. MDA and POD can be used as critical indicators of the resistances to $\mathrm{Cd}$ and $\mathrm{Pb}$ stress and their interaction at seed germination and an early stage of seedling growth in Rhus typhina. Our results also confirmed that Rhus typhina was never completely inhibited in its early growth and could be used for phytoremediation on $\mathrm{Pb}$ and $\mathrm{Cd}$ contaminated soil, although seed germination and seedling growth of Rhus typhina decreased with increasing $\mathrm{Cd}$ and $\mathrm{Pb}$ whether single or combine stress.

\section{Acknowledgements}

This work was supported by the Department of Science and Technology of Jilin Province (20190303078SF and 20200801031GH).

\section{Conflict of Interest}

The authors declare no conflict of interest.

\section{References}

1. SENEVIRATNE M., RAJAKARUNA N., RIZWAN M., MADAWALA H.M.S.P., OK Y.S., VITHANAGE M. Heavy metal-induced oxidative stress on seed germination and seedling development: a critical review. Environmental Geochemistry and Health, 41 (4), 1813, 2019.

2. HASSAN M., SIMEEN M. Oxidative stress and antioxidant defense mechanism in mung bean seedlings after lead and cadmium treatments. Turkish Journal of Agriculture and Forestry, 55, 2014

3. SHETEIWY M. S., DONG Q., AN J., SONG W., GUAN Y., HE F., HUANG Y., HU J. Regulation of $\mathrm{ZnO}$ nanoparticles-induced physiological and molecular changes by seed priming with humic acid in Oryza sativa seedlings. Plant Growth Regulation, 83 (1), 27, 2017.

4. SCHUTZENDUBEL A., POLLE A. Plant responses to abiotic stresses: heavy metal-induced oxidative stress and protection by mycorrhization. Journal of experimental botany, 53 (372), 1351, 2002.

5. DEY S.K., DEY J., PATRA S., POTHAL D. Changes in the antioxidative enzyme activities and lipid peroxidation in wheat seedlings exposed to cadmium and lead stress. Brazilian Journal of Plant Physiology, 19, 53, 2007.

6. LESMANA S.O., FEBRIANA N., SOETAREDJO F.E., SUNARSO J., ISMADJI S. Studies on potential applications of biomass for the separation of heavy metals from water and waste water. Biochemical Engineering Journal, 44, 19, 2009.

7. CLEMENS S. Toxic metal accumulation, responses to exposure and mechanisms of tolerance in plants. Biochimie, 88 (11), 1707, 2006.

8. DAGO A'., GONZA'LEZ I., ARIN ${ }^{\sim}$ C., DI 'AZ-CRUZ J M., ESTEBAN M. Chemometrics applied to the analysis of induced phytochelatins in Hordeum vulgare plants stressed 
with various toxic non-essential metals and metalloids. Talanta, 118, 201, 2014.

9. APRILE A., SABELLA E., FRANCIA E., MILC J., RONGA D., PECCHIONI N., FERRARI E., LUVISI A., VERGINE M., DE BELLIS L. Combined effect of cadmium and lead on durum wheat. International Journal of Molecular Sciences, 20, 5891, 2019.

10. ABIOYE O.P., AINA P.F., IJAH J.U., ARANSIOLA A.S. Effects of cadmium and lead on the biodegradation of diesel-contaminated soil. Journal of Taibah University for Science, 13 (1), 628, 2019.

11. BEWLEY J.D. Seed germination and dormancy. The Plant Cell, 9 (7), 1055, 1997.

12. HSU F.H., CHOU C.H. Inhibitory effects of heavy metals on seed germination and seedling growth of Miscanthus species. Botanical Bulletin of Academia Sinica, 33 (4), 335, 1992.

13. RODRÍGUEZ-ALONSO J., SIERRA M.J., LOMINCHAR M.Á., MILLÁN R. Effects of mercury on the germination and growth of Quercus ilex L. seedlings. Environmental Science and Pollution Research, 26 (30), 30930, 2019.

14. BARCELO' J., POSCHENRIEDER C. Plant water relations as affected by heavy metal stress: A review. Journal of Plant Nutrition, 13 (1), 1, 1990.

15. SEREGIN I.V., IVANOV V.B. Physiological aspects of cadmium and lead toxic effects on higher plants. Russian journal of plant physiology, 48 (4), 523, 2001.

16. GONZALES DE SOUZA G., MENDES PINHEIRO A.L., SILVA J.A. VERONEZE-JÚNIOR V., CARVALHO M., BERTOLI A.C., BARBOSA S., DE SOUZA T.C. Morphophysiological Tolerance Mechanisms of Talinum patens to Lead. Water, Air, Soil Pollution, 229, 4, 2018.

17. MAHDIEH S., GHADERIAN S.M., KARIMI N. Effect of arsenic on germination, photosynthesis and growth parameters of two winter wheat varieties in Iran. Journal of Plant Nutrition, 36 (4), 651, 2013.

18. VA'ZQUEZ DE ALDANA B., GUNDEL P., GARCIA CRIADO B., GARCI 'A CIUDAD A., GARCI 'A SA'NCHEZ A., ZABALGOGEAZCOA I. Germination response of endophytic Festuca rubra seeds in the presence of arsenic. Grass \& Forage Science, 69 (3), 462469, 2014.

19. COKKIZGIN A., COKKIZGIN H. Effects of lead $\left(\mathrm{PbCl}_{2}\right)$ stress on germination of lentil (Lens culinaris Medic.) lines. African Journal of Biotechnology, 9 (50), 8608, 2015.

20. LOVETT-DOUST J., LOVETT-DOUST L. Modules of production and reproduction in a dioecious clonal shrub, Rhus Typhina. Ecology, 69 (3), 741, 1988.

21. GANDHI K.N. Staghorn sumac: Rhus typhina or R. hirta (anacardiaceae). Rhodora, 118 (974), 232, 2016.

22. WANG C., LIU J., XIAO H., ZHOU J. Differences in leaf functional traits between Rhus typhina and native species. Clean Soil Air Water, 44 (11), 1591, 2016.

23. WANG G., JIANG G., YU S., LI Y., LIU H. Invasion possibility and potential effects of Rhus typhina on Beijing municipality. Journal of Integrative Plant Biology, 50 (5), $522,2008$.

24. KUDISH M. Adirondack Upland Flora: an Ecological Perspective. Saranac, NY, Chauncy Press, 320, 1992.

25. XU Z., ZHOU Q., LIU W. Joint effects of cadmium and lead on seedlings of four Chinese cabbage cultivars in northeastern China. Journal of environmental sciences, 21, $1598,2009$.

26. ZITER C., TURNER M.G. Current and historical land use influence soil-based ecosystem services in an urban landscape. Ecological Applications, 28 (3), 643, 2018.
27. HEATH R.L., PACKER L. Photoperoxidation in isolated chloroplasts I. Kinetics and stoichio metry of fatty acid peroxidation. Archives of Biochemistry and Biophysics, $\mathbf{1 2 5}, \mathbf{1 8 9}, \mathbf{1 9 6 8}$

28. BRADFORD M.M. A rapid and sensitive method for the quantitation of microgram quantities of protein utilizing the principle of protein-dye binding. Analytical Biochemistry, 72, 248, 1976.

29. GIANNOPOLITIS C.N., RIES S.K. Superoxide dismutase: I. occurrence in higher plants. Plant Physiology, 59, 309, 1997.

30. POLLE A., OTTER T., SEIFERT F. Apoplastic peroxidases and lignification in needles of Norway spruce (Picea abies L.). Plant Physiology, 106 (1), 53, 1994.

31. SINGH S., PARIHAR P., SINGH R., SINGH V.P., PRASAD S.M. Heavy metal tolerance in plants: role of transcriptomics, proteomics, metabolomics, and ionomics. Frontiers in Plant Science, 6, 1143, 2016.

32. JALMI S.K., BHAGAT P.K., VERMA D., NORYANG S., TAYYEBA S., SINGH K., SHARMA D., SINHA A.K. Traversing the links between heavy metal stress and plant signaling. Frontiers in plant science, 9, 12, 2018.

33. BAE J., BENOIT D.L., WATSON A.K. Effect of heavy metals on seed germination and seedling growth of common ragweed and roadside ground cover legumes. Environmental Pollution, 213, 112, 2016.

34. TAGHIZADEH M., SOLGI E. Impact of Heavy Metal Stress on In Vitro Seed Germination and Seedling Growth Indices of Two Turfgrass species. Journal of Rangeland Science, 7 (3), 220, 2017.

35. WANG J., LI W., ZHANG C., KE S. Physiological responses and detoxific mechanisms to $\mathrm{Pb}, \mathrm{Zn}, \mathrm{Cu}$ and $\mathrm{Cd}$ in young seedlings of Paulownia fortunei. Journal of Environmental Sciences, 22, 1916, 2010.

36. BARUAH N., MONDAL S.C., FAROOQ M., GOGOI $\mathrm{N}$. Influence of heavy metals on seed germination and seedling growth of wheat, pea, and tomato. Water, Air, \& Soil pollution, 230 (12), 273, 2019.

37. NAGAJYOTI P.C., LEE K.D., SREEKANTH T.V.M. Heavy metals, occurrence and toxicity for plants: A review. Environmental Chemistry Letters, 8 (3), 199, 2010.

38. LOU Y., ZHAO P., WANG D., AMOMBO E., SUN X., WANG H., ZHUGE Y. Germination, physiological responses and gene expression of tall fescue (Festuca arundinacea Schreb.) growing under $\mathrm{Pb}$ and $\mathrm{Cd}$. PLoS ONE, 12 (1), e0169495, 2017.

39. TAUQEER H.M., ALI S., RIZWAN M., ALI Q., SAEED R., IFTIKHAR U., AHMAD R., FARID M., ABBASI G.H. Phytoremediation of heavy metals by Alternanthera bettzickiana: growth and physiological response. Ecotoxicology and Environmental Safety, 126, 138, 2016.

40. COBBETT C. Phytochelatins and metal-lothioneins: roles in heavy metal detoxification and homeostasis. Annual Review of Plant Biology, 53, 129, 2002.

41. CORTÉS-ESLAVA J., GÓMEZ-ARROYO S., RISUEÑO M.C., TESTILLANO P.S. The effects of organophosphorus insecticides and heavy metals on DNA damage and programmed cell death in two plant models. Environmental Pollution, 240, 77, 2018.

42. SÜMER ERCAN, F., ERCAN, N., DEMIREZEN YILMAZ, D. Effect of heavy metal stress on antioxidant enzymes and DNA damage in Nasturtium officinale R. Br.(watercress). Toxin Reviews, 38 (4), 328, 2019.

43. APEL K., HIRT H. Reactive oxygen species: metabolism, oxidative stress, and signal transduction. Annual Review of Plant Biology, 55, 373, 2004. 
44. FAROOQ M.A., ALI S., HAMEED A., ISHAQUE W., MAHMOOD K., IQBAL Z. Alleviation of cadmium toxicity by silicon is related to elevated photosynthesis, antioxidant enzymes; suppressed cadmium uptake and oxidative stress in cotton. Ecotoxicology and Environmental Safety, 96, 242, 2013.

45. BASHRI G., PRASAD S.M. Indole acetic acid modulates changes in growth, chlorophyll a fluorescence and antioxidant potential of Trigonella foenum-graecum L. grown under cadmium stress. Acta Physiologiae Plant, 37, 1745, 2015.

46. LI S., LEI N., CHEN J. Differential Effects of Natural Palygorskite and its Modified Form on Alleviation of Heavy Metals Toxicity to Tomato Grown in Soil Contaminated with $\mathrm{Cd}, \mathrm{Pb}$ and $\mathrm{Zn}$. Polish Journal of Environmental Studies, 28 (6), 2019.

47. GAO Y., MIAO C.Y., XIA J., LUO C.Y., MAO L., ZHOU P., SHI W. Effect of citric acid on phytoextraction and antioxidative defense in Solanum nigrum L. as a hyperaccumulator under $\mathrm{Cd}$ and $\mathrm{Pb}$ combined pollution. Environmental Earth Science, 65, 1923, 2012.
48. MAO X., XB-CHEN L.L. Effects of heavy metal $\mathrm{Pb}$ and $\mathrm{Cd}$ stress on physiological characteristics of Japanese honeysuckle. Applied ecology and environmental research, 17 (3), 6415, 2019.

49. CHEN Y.P., LIU Q., YUE X.Z., MENG Z.W., LIANG J. Ultrasonic vibration seeds showed improved resistance to cadmium and lead in wheat seedling. Environmental Science and Pollution Research, 20 (7), 4807, 2013.

50. SUN R.L., ZHOU Q.X., SUN F.H., JIN C.X. Antioxidative defense and proline/phytochelatin accumulation in a newly discovered Cd-hyperaccumulator, Solanum nigrum L. Environmental and Experimental Botany, 60 (3), 468, 2007.

51. DAI W., KE X., LI Z., GAO M., WU L., CHIRISTIE P., LUO Y. Antioxidant enzyme activities of Folsomia candida and avoidance of soil metal contamination. Environmental Science and Pollution Research, 25 (3), 2889, 2018.

52. SRIVASTAVA R.K., PANDEY P., RAJPOOT R., RANI A., DUBEY R. Cadmium and lead interactive effects on oxidative stress and antioxidative responses in rice seedlings. Protoplasma, 251 (5), 1047, 2014. 
